\section{BA Institute of \\ YK Business Administration \\ 六下 \\ Karachi \\ Leadership and Ideas for Tomorrow}

\section{Business Review}

Volume 1 Issue 1

July - December 2006

7-1-2006

\title{
The influence of children on family purchase decisions: $A$ phenomenological approach
}

\author{
Usman Majeed \\ Engro Polymer \& Chemicals Limited \\ Nadia S. Banoori \\ Engro Polymer \& Chemicals Limited
}

Follow this and additional works at: https://ir.iba.edu.pk/businessreview

Part of the Family, Life Course, and Society Commons, Marketing Commons, and the Transpersonal Psychology Commons

\section{(c) (1)}

This work is licensed under a Creative Commons Attribution 4.0 International License.

\section{Recommended Citation}

Majeed, U., \& Banoori, N. S. (2006). The influence of children on family purchase decisions: A phenomenological approach. Business Review, 1(1), 175-190. Retrieved from https://doi.org/10.54784/ 1990-6587.1103

This article is brought to you by iRepository for open access under the Creative Commons Attribution 4.0 License and is available at https://ir.iba.edu.pk/businessreview/vol1/iss1/15. For more information, please contact irepository@iba.edu.pk. 


\section{The influence of children on family purchase decisions: A phenomenological approach}

\section{Cover Page Footnote}

This study was possible because of the support of the Principal of the school, the children interviewed, and their parents, and instructors that helped us in fine-tuning this research. 


\title{
DISCUSSION
}

\section{The Influence of Children on Family Purchase Decisions: A Phenomenological Approach}

\begin{abstract}
Usman Majeed
Abstract

Nadia S. Banoori

This study was conducted to understand the influence of school-going children between seven to ten years of age on family's buying decision-making in the area of North Nazimabad. A sample of three children was chosen to be interviewed and were asked a number of questions related to their influence on purchase. Later, their parents were interviewed to counter-check their perceptions about their children's influence. The results showed that children did exert some influence on decisions, especially in cases where the product was for their own use. Another result was that the level of understanding of the children was high enough to understand their parents' point of view upon refusal of a demand.
\end{abstract}

\section{Acknowledgements}

This study was possible because of the support of the Principal of the school, the children interviewed, and their parents, and instructors that helped us in fine-tuning this research.

\section{Introduction}

$\mathrm{R}$ ecent changes in demographic and household structure have increased children's R impact on purchase decisions (Ekstrom, Foxman, \& Tansuhaj, 1989). Although these changes in Pakistan have been more gradual, they are noticeable. Children are more aware today than they were before. They have more television channels to watch than kids ten years back did. Also, more working parents means that children take more decisions on their own.

Pakistan does not have a very research oriented culture. The total amount of money approved for research is a meagre Rs. 322 million in a year (Mamoona Amjad, 2005). Although research has been conducted about adolescents in the West, it has the inherent problem of being ill-suited to the culture and environment of a developing country like Pakistan where the average incomes are lower, and family lifestyles are different. Given these limitations, we felt that a formal research effort needed to be exerted to find out about the degree to which children now have influence in the purchase decisions. We seek to find out the different product categories this influence operates in and then counter-check from parents about how they perceive their children's influence to be.

In order to achieve this, we conducted two sets of in-depth interviews: one with the children, and the other with their parents. 


\section{Conceptual Context}

Some research in related areas exists conducted by Western researchers. The majority of family studies have focused more on the consumer socialization of children and less on how the children influence purchase decisions (Ekstrom et al., 1989).

It would be useful to understand the way children think, the interplay among their emotions and the way they affect him/her. Some children feel bad after they do something that their parents do not want them to do. Others may feel happy since they did end up getting what they wanted. This perception is important in understanding whether the children will exercise their will in decision-making if it is against the desires of the parents. Kristin Lagattuta (2005) shares that if parents object, most children feel bad. So in this sense, indirectly parents may influence the type of influence the children have. For example, if parents do not like children to have a say in buying petrol, then the children may not exercise it. All children do, however, feel good after they have gotten what they wanted, according to the study.

Ego may determine the degree of influence exerted by a child. The research by Hauser, and Safyer (1994) states that children pass through different stages of their ego development. These stages are the preconformist, the conformist, and the postconformist stages. Children in the pre and conformist stages are likely to exert influence for things they use to conform to peers and others whereas at the post-conformist stage, they may choose what they identify with themselves.

The research by Knafo, and Schwartz (2003) explains when and how the family values are perceived accurately by children. The more accurately children understand parental values, the greater they are likely to be influenced by them. The study states that accuracy in understanding occurs when the parental messages are consistent, when parents show warmth and there is agreement between parents about the family values. If we can understand what brand names mean to children and the degree to which they are conscious, we can understand the kind of influence they are likely to exert in order to get them. Results of Achenreiner and John's study (2003) show that children are brand conscious as early as 8 years of age. Children start to understand consumption symbolism as they reach 12 years of age. This may mean that they may start exerting greater influence at this age.

The degree to which one is materialistic determines to an extent our predispositions towards buying products. More materialistic people or children are likely to buy more things, and are likely to apply greater pressure on their parents to buy particular things than others. Goldberg, Gorn, Perachhio, and Bamossy (2003) found that more materialistic youth shop more, save less, are more interested in new products, and more responsive to promotional efforts. Materialistic parents tend to have children who are materialistic too.

The study by Ekstrom et al. (1989) reveals that influence of children in decisionmaking is perceived differently by family members. The parents perceive their influence 
to be less than what the children consider it to be. It also states that children tend to have greater influence for products that are less expensive and are for their own use.

Meyer and Anderson (2000) explain that children aged 8-12 are influenced by their peers and parents in decision-making. It is important to understand all the factors that shape the children's choice and the way they use it. Although the children may be influencing or making decision, but these decisions may be affected by the values of their parents and peers. This suggests that children may want to have a say in decisionmaking just because their peer(s) who is considered an opinion leader also has it. As children grow older, the influence of parents diminishes, and the influence of peers grows. The study also explains that conformity may determine if the purchase is made independently or dependently. Individuals appear to act in a way that is consistent with social groups they identify themselves with. Although most children make purchases in the company of their parents, they exert influence over them according to what their peers think is fashionable and what they wear.

The study by Chiou, Huang, and Chuang (2005) reveals that children tend to want those things more that are endorsed by celebrities that they like. If they want something more, they are likely to try to influence the decision-making more. Also the greater control children have on their purchases (money, permission) the greater the likelihood of their being influenced by celebrities.

The operational variables we will be considering in our study are the influence which may be seen to have an effect on purchase decisions; family which means a social unit comprising of at least one parent/guardian and one child; purchase decision-making that is the actual act of deciding between alternatives and finally purchasing the product; parents or biological or surrogate guardians; needs which are the essential requirements of the child as perceived by the parent; and want is something that children could do without but perhaps like to have but parents would not like them to have it all the time.

\section{Research Questions}

In this discovery-driven approach, we wanted to find out how the influence of children operates within the Pakistani social setting. Do the children have any degree of influence or not? What kind of products do they exert an influence on? Do the parents perceive the influence of their children in the same manner as the children perceive it to be? What happens if the children do exert influence but parents refuse to listen? In order to shed some light on these, we focussed on the following three research questions:

1. Do children's preferences influence parental purchase decisions?

2. What kind of product categories do they have influence in?

3. To what extent is the influence of children in purchase decisions known to parents?

In designing these questions, we assumed that it would be possible to obtain the answers to these questions through a single session of in-depth interviewing. Another 
underlying assumption inherent in the questions is that the children themselves are aware about the influence they exert on the purchase decisions.

Researches on children have focused on different age groups. Achenreiner and John (2003) focused on children between 8 to 16 years; Anderson and Meyer (2000) have focused on children between 8-12 years; Kenneth D. Bahn (1986) focused on children between 4-9 years; and Carlson and Grossbart (1988) included children from 2-9. Given this and the fact not all researches are recent, there is limited cross-sectional alignability among each other and to our purpose. These reasons, along with others, justify conducting another study geared towards understanding the influence of children aged 7-10 years in purchase decisions.

\section{Sample Characteristics}

Three children ( 2 boys, 1 girl) aged 8-10 years from a junior school in North Nazimabad, Karachi, were selected. According to the Principal of the school, all were above average students in terms of academic performance as measured by school examinations. Child 1 was from grade three and was nine years old, Child 2 was in grade three and eight years old, and Child 3 was in grade five and ten years old.

Parent 1, Parent 2 and Parent 3 were not employed at any institution, private or public.

We chose the school that we chose because we believed that gaining entry would be easier and greater cooperation could be enlisted since one of the researchers was an old student of the same school and had a good rapport with the Principal.

All the children selected lived in the same area as the school. This along with the fact that the researcher had previous rapport with the Principal may have to some extent skewed the results in some manner although care was taken to minimize such occurrences. Also, cross-sectional extrapolation of this study with other areas may not be suitable.

\section{Design Methodology}

A qualitative research orientation has been employed since the focus of the study was to discover and understand rather than generalize and factualize. Under the qualitative paradigm, the phenomenological approach (Rick Houser, 1998) was subscribed to since it matched our purpose of gaining greater understanding about the influence of children. A case study could also have been a useful method if the children and their parents had consented to devote greater time and effort to the study and equal time was dispensable by the researchers.

The components of the research must form an interrelated set of interactive components, each affecting the other, as Maxwell (1996) has pointed out. The purpose of gaining understanding and the nature of research questions influenced the method of 
phenomenology that was adopted as did the validity considerations that could be controlled to an extent in this research.

\section{Data Collection}

The sampling of the school was based on convenience as well as judgement. We believed that given the available resources, the school selected would supply the richest information and best cooperation. Any drawback that may be pointed out in the sampling plan is most likely to be from the perspective of a positivist since the results may not be able to be generalized to the larger population of children. However, as far as this study is concerned, even that is a strength since it will allow us to understand in much greater detail the individuals and their decision influence than if we had used the post-positivist paradigm. Our focus is on depth and not on breadth.

The principal suggested 12 children out of which three were selected randomly. The sample size of three was also based on judgement about the number of interviews that would be completed in the time allowed to us by the school. The children were asked a number of questions related to their influence on the buying behavior of their parents. The children were provided an environment (the school premises) that they were familiar with and hence comfortable in. Given the favorable ambiance the children were encouraged to speak their minds without any external pressure. The interview lasted a span of 15-20 minutes with each child. Later, at least one parent of each child was contacted over the telephone and asked questions for validity and verification. Both the interviews of the child and the parent were then matched to ensure accuracy. The interviews were conducted primarily in Urdu so that the respondents could understand and reply in a better way.

A focus group discussion was not used since the young minds are impressionable and can easily be influenced by an assertive child.

Since the purpose of the interviews with the parents was just to verify whether they perceived their children's purchase influence in the same manner as the children, the duration was only about 10 minutes. The interviews with the parents were conducted over the telephone since otherwise they would have to be called to the school premises and that would have been difficult for the parents with busy schedules.

Validity and Reliability: Validity threats were minimized by applying two very important concepts. Firstly, all interviews were audio recorded so that nothing was missed out. The audio recording was then transcribed carefully so that all key insights are transferred accurately into a hard copy version. During the interview, care was taken by the interviewer to keep verifying the answers given by the participants to serve as a primitive form of member check, keeping in mind that measures for verification should be built into the research (Morse, Barret, Mayan, Olson, \& Spiers, 2002). 
"Research is only as good as the investigator. It is the researcher's creativity, sensitivity, flexibility and skill in using the verification strategies that determines the reliability and validity of the evolving study." (Morse et al., 2005, p. 10).

In line with this, effort was made to be as responsive as possible in the research process. The fatigue and responsiveness of the interviewer, that are vital for reliability (Anderson $\&$ Arsenault, 1998) were also kept in check since the interviews never lasted for more than 15 minutes.

Secondly, after the preliminary interviews with the children, the parents of each child were also interviewed and relevant facts were gathered, to match the insights presented by both. Any discrepancy would have meant that the information given in the initial interview was dubious and lacked reliability. The idea was to uncover the degree to which children influence their parents' buying decisions.

The fact that the children were interviewed without any prior intimation also added to the validity of the research. The children were not given ample time to think up on answers that were not genuine. Although the Principal was approached much earlier, the children had no intimation regarding the interview. The children caught unawares hopefully were honest when answering the questions.

Also both researchers acted as multiple analysts to fine-tune each others' work giving the study some degree of "scorer reliability" (Cooper \& Schindler, 2003, chap. 9, p. 316). The same approach was used to reduce validity and reliability threats in translation of insights.

Against our assumption, all of the children suggested by the Principal were willing to take part in the study. The questions were designed in as simple a manner as possible so that the children could easily understand. The questions were asked in Urdu so that they could reply freely and easily. This helped against non-response error.

\section{Data Analysis}

For the sake of analysis, the findings of the interviews were classified according to the themes (Siedman, 1998) and the unit of analysis was taken to be the child (Houser, 1998).

Findings: The three children interviewed were given code names; Child 1, Child 2, and Child 3, and their respective parents as Parent 1, Parent 2, and Parent 3. The interview schedule prepared, had some sections according to which we shall report the findings as well.

When analyzing the data it is imperative that the research questions are kept in mind. The findings in data collection are then translated into a language that would answer all the research questions. The idea is to achieve what the research was being conducted for. For analysis purposes the following four domains are highlighted. 
It was refreshing to find that the young children were very mature and understanding. Maturity has a lot to do with the level of intelligence as well. The children chosen were ones who were doing very well academically. This reflects a certain degree of bias on the part of the Principal since the children who were poor or even average performers were not given a chance. Therefore it can be explored that intelligence and maturity level are directly related (Larsson, Nordberg, Fried, Edbom, Ekman, \& Rydelius, 2002).

All children did not expect their parents to ask them if they wanted to buy anything. In fact they always asked their parents without any inhibitions if they wanted to purchase anything.

I usually tell them what I want... otherwise why go? (Child 3)

According to the children, their parents always bought them the important things that they needed. Upon refusal to purchase a certain product the children's reaction was that of ultimate maturity since they did not feel bad and did not insist. However, Child 1 approached the older brother in event of a refusal from a parent, Child 2 saved part of his pocket money until the time he had enough to buy the desired product and Child 3 did not even try to buy the product. Child 3 refers to toys as "useless" items that have no practical use, are flimsy and break easily.

I might as well get a set of markers or colors that will last me a long time (Child 3).

This is a reflection on the child's level of understanding. All children understood very well why their parents may refuse to buy them a product. They knew that either the product was bad for their health or simply because the parents say "no" and parents know best. The children seemed very obedient and seldom argued with their parents.

It was pointed out by the children many a time that they all possessed those things that they needed. They were well-aware of their limits and they never tried to cross them. They knew that they could only get the more expensive items on a birthday or upon doing well in school. They were aware of the reward system where the parents told them to do well in school and they would buy them the toy they have wanted to buy for such a long time. The incentive giving seemed to work as all children stated that they would work hard to do well in school to get the reward in the form of a toy or any other product they wanted.

If I get good marks then they will get me the expensive item (Child 2).

Child 2 here is mature enough to understand that he would get the expensive toy only if he works hard and gets good grades. The child is learning the lesson of life, that nothing can be achieved without hard work. The child must learn the goal and reward game; the goal being good grades and reward, the toy. 
Parents take an active part in their children's social communication process. Parental influence on the consumer behavior of their offspring is situation-specific (George P. Moschis, 1985). This statement was further reinforced, when the parents were asked to give an account of a recent episode where they had to refuse their child something.

He has recently been breaking many toys and he knows that he is not doing the right thing by doing so (Parent 2).

The fact that the parent had effective direct communication with the child, whereby the child understood the point of view of the parent reflects on the level of discipline and maturity.

\section{Child Preferences}

Children certainly had their own preferences in whatever they purchased and it is felt that parents encouraged this freedom. Parents tried not to impose a certain product on children. In fact parents had to give detailed explanations for making children consume a certain product or not to consume something.

We explain it to him... these days children want an explanation for everything. Even if I scold him over something he asks why he got a scolding. And he understands perfectly (Parent 2).

The degree to which one is materialistic determines to an extent our predispositions towards products. More materialistic people or children are likely to buy more things, and are likely to apply greater pressure on their parents to buy particular things than others (Goldberg, Gorn, Perachhio and Bamossy, 1978). This particular phenomenon was very obvious in the research conducted on Pakistani school children. After talking to the parents it was realized that children's desires for a particular product is directly related to the way they are brought up and the ideas that are instilled in them.

If it is an important thing for me then she (mother) will get it. If it is a useless thing then she will get it but then I can't ask for too many useless things (Child $3)$.

Here the child is aware of the fact that the parent will only purchase toys and games very seldom. The child knows about the limitations and has been brought up in such a way that unreasonable demands will not arise. Even though all the children do know that they must speak up in case of a need arising, they know that all their wants will not be satiated. Then the children may use an alternative means of getting a product they want. They may approach the mellower parent or an older sibling to purchase the product refused by one of the parents. Children seem to have preferences for different product categories. 


\section{Product Category}

\section{Food Items}

According to the children, parents do not really indulge in food items such as toffees, and pizza. They all seem to enjoy home food, a favorite eating item being pizza, that two children said they liked. But the children are taken out to eat occasionally. Parents do let them eat everything but in moderation. Overindulgence is highly discouraged by all three parents. Children do not like to indulge in certain food items because of what they have learnt from experience. Child 3 had teeth problems so stays away from toffees and Child 2 had a tendency to gain weight so he stays away from fattening foods such as pizza.

I like pizza but parents say that I will get fat so they don't let me eat too much of it. But they let me eat it sometimes. We went to Pizza Hut day before yesterday (Child 2).

Toys

Being children they all had their preferences in the kind of toys they liked. Some liked Playstation, some Power Rangers yet others Teddy Bears. But they all knew that they could not get toys all the time. Buying toys is an occasional activity and that they will only get one on a birthday or when promised after fulfilling a promise to the parent. Children seem to be happy to fulfill the desires of the parents of getting good grades. It was not the fact that they were getting a toy that was the incentive but the fact that getting good grades will make the parents happy that drove the children to do well in school.

I will get them otherwise too but they are happier if I get good grades and I want to see them happy (Child 3).

\section{Clothing}

All children seem to have great deal of input in the kind of clothes they wear. They all go with their parents to shop for clothes and the parents always ask them what they like in the shop. Parents always responded by purchasing whatever their children liked. One of the reasons being that children otherwise would never wear what they do not particularly like.

I buy what I like. We go to the shop and I point at something that I like. My mother tells the shopkeeper (referred to as Uncle) to take it out. If I still like the item up close then she buys it for me (Child 2).

I do all my clothes shopping. I go with parents and choose my own clothes and they always buy me whatever I want (Child 1). 


\section{Parental Buying Pattern}

There was perfect understanding of parental intentions to the child. The parents usually purchased those items that the children "needed". But they drew the line when the item was an expensive one or one that provided only entertainment. Items that were "needed" by the children were stationery, books (even comic books and other fiction in addition to academia related books), and an occasional toy.

Parents claimed that they did not want their children to feel that they can always have what they desire.

...we want to tell them that they cannot get everything they want. We take them out for dinner once a month only so that they know that their parents have limited funds. We handle them very systematically. Now his birthday is coming up so his demands are in the air (Parent 2).

We do get them the essentials that we feel they need. For other things we do satisfy their demands but a little late so that they don't get used to getting whatever they demand. But his reaction is very cool (Parent 2).

\section{Degree of Influence on Parents}

All three children said that they were taken to the supermarket every weekend when they were home. The children seemed to believe that they were taken every weekend only since that was the time they were available at home, the rest of their week being spent at school. However Parent 2 said that she would rather not spoil her child by taking them out very often. According to her, everything must be done within limits. Parent 1 claimed that her child was new to Pakistani environment since he had just moved from the USA and that he had never gone out shopping in Pakistan. Influence of children in decision-making is perceived differently by family members. The parents perceive their influence to be less than what the children consider it to be. It also states that children tend to have greater influence for products that are less expensive and are for their own use (Ekstrom et al., 1989). This is exactly what was discovered in this particular research.

All children stated that they understood why their respective parents didn't buy them a particular item. Child 1 stated that whenever his parents refused to get him something, he saved his pocket money till he had enough collected to buy the item. Upon not being asked whether they wanted to buy something they did not seem to mind much.

How would they know we need something unless we tell them? (Child 3)

The more accurately children understand parental values, the greater they are likely to be influenced by them. A study states that accuracy in understanding occurs when the parental messages are consistent, parents show warmth, and there is agreement 
between parents about the family values (Knafo and Schwartz, 2003). As children go through the consumer socialization process, the parental values are automatically instilled in them. As they watch their parents make daily purchases of goods, they are learning from them in some way.

\section{Conclusion}

Children speak their minds without inhibitions but are well-aware of the fact that they must respect the sayings of the parents. Children do not think of parents as unreasonable when they were refused a certain item. Instead, they understand perfectly and know their place. The children have more of a say in products that are directly connected to them. Extravagance and indulgence is highly objected upon by parents. Children want to please parents by getting good grades meaning that they are not very materialistic. For them, being in the good books of the parents is more important. Parents do like rewarding their children and fulfill all promises made to them.

Some of the previous theories were supported. Knafo and Schwartz's (2003) study may hold true since unless the children understood parental values, they would not have understood reasons for refusal of demands.

Achenreiner and John's study (2003) states that children start to understand consumption symbolism as they reach 12 years of age when they exert greater influence. However, the children (aged 8-10 years) did exert influence. This may well be due to cultural or socioeconomic differences of the children in the two studies and warrants a further investigation.

\section{Future Directions}

It is hoped that the study has some application in Pakistan. Potentially there are many; the study may be used by confectionery manufacturers, various schools, research firms, children apparel makers, or toy manufacturers to design their communications and promotion more effectively by keeping in mind the influence of their target child consumers. Since there are innumerable applications, a further study can be conducted in future so as to elaborate and expand upon the study already conducted.

This qualitative research was conducted on a small scale and the insights of only three children were included. However, this research can be taken a step further by carrying out in-depth interviews on a larger sample. A good sample size would be seven to ten children. However, "good" depends on the richness rather than number of respondents and the collection should be considered complete when additional interviews yield no new insights, or when there is saturation of information (Siedman, 1998). Making the interviews longer may not be advisable since children have shorter concentration spans and they may not sustain interviews longer than 20 minutes. Having a larger sample would bring richness to the data as more varied views are included as part of the research. Also, following the triad format of interviewing (Siedman, 1998) would perhaps be more suitable and enhance validity of the findings. 
Although the interviewing at the school premise was assumed to put the children at ease, it may have had a negatively moderating effect and may have made the children more tensed than relaxed. A triangulative study conducted at the homes of children could be used to compare the reliability of the procedure.

Most research papers used for references used quantitative techniques. This study has used some of the research findings and tried to discover them through the phenomenological approach. This may be seen a triangulation procedure as well as a handicap.

Extending on the study by Chiou et al. (2005), a study may be conducted on the effect of cartoon and animated characters on the purchase decision of children. The findings were inadequate to prove Meyer and Anderson's (2000) theory that children are affected by peer preferences. Another study may be conducted to explore this theory.

Future research may be conducted to find out the relationship between the intelligence of the child and his/her maturity level.

\section{REFERENCES}

Achenreiner, G.B. \& John, D.R. (2003), “The Meaning of Brand Names to Children: A Developmental Investigation”, Journal of Consumer Psychology, 13(3), 205-219.

Amjad, Mamoona (2005, September 26). "Promoting Research for Development", The Dawn, pp. A1, A4.

Anderson, Gary \& Arsenault, Nancy (2nd ed.) (1998). Fundamentals of Educational Research, UK: Routledge.

Anderson, H.C. \& Meyer, D. J.C. (2000). "Preadolescents and Apparel Purchasing: Conformity to Parents and Peers in The Consumer Socialization Process", Journal of Social Behavior and Personality, 15(2), 243-257.

Bahn, Kenneth D. (1986). "How And When Do Brand Perceptions and Preferences First Form? A Cognitive Development Investigation", Journal of Consumer Research, $13,382-393$.

Carlson, Les \& Grossbart, Sanford (1988). "Parental Style and Consumer Socialization of Children", Journal of Consumer Research, 15, 77-94.

Chiou, J.S., Huang, C.Y. \& Chuang, M.C. (2005). “Antecedents of Taiwanese Adolescents' Purchase Intention Toward the Merchandise of a Celebrity: The Moderating Effect of Celebrity Adoration", The Journal of Social Psychology, 145(3), 317-332.

Cooper, D.R. \& Schindler, D.S. (8th ed.) (2003). Business Research Methods.

Ekstrom, K.M., Foxman, E.R. \& Tansuhaj, P.S. (1989). “Family Members’ Perceptions of Adolescents' Influence in Family Decision Making", Journal of Consumer Research, $15,482-490$. 
Goldberg, M.E., Gorn G.J., Peracchio, L.A. \& Bamossy, G. (2003). “Understanding Materialism Among Youth”, Journal of Consumer Psychology, 13(3), 278-288.

Goldberg, Marvin E. \& Gorn, Gerald J. (1978). "Some Unintended Consequences of TV Advertising to Children”, Journal of Consumer Research, 5, 22-29.

Hadary, Gideon (1943). "The Candy-Consumer - How Much will he Buy in the Postwar Period?", The Journal of Business, 96-100.

Hauser, S.T. \& Safyer, A.W. (1994). "Ego Development and Adolescent Emotions", Journal of Research on Adolescence, 4(4), 487-502.

Heslop, Louise A. \& Ryans, Adrian B. (1980). "A Second Look at Children and the Advertising of Premiums", Journal Of Consumer Research, 6, 414-421.

Horst, J.S., Oakes, L.M. \& Madole, K.L. (2005). "What Does it Look Like and What Can it Do? Category Structure Influences How Infants Categorize", Child Development, 76(3), 614-631.

Houser, Rick (1998). Counseling and Educational Research: Evaluation and Application. California: Sage Publications.

Knafo, A. \& Schwartz, S.H. (2003). "Parenting and Adolescents' Accuracy in Perceiving Parental Values", Child Development, 74(2), 595-611.

Lagattuta, K.H. (2005). "When y ou Shouldn't Do What y ou Want to Do: Young Children's Understanding Of Desires, Rules, And Emotions", Child Development, 76(3), 713-733

Larsson, J., Nordberg, L., Fried, I., Edbom, T., Ekman, S. \& Rydelius, P.A. (2002).

"An Evaluation of a Short Questionnaire for Parents about their School-aged Children's Global Maturity Level”, Child Psychiatry and Human Development, 33(1), 59-73.

Macklin, M. Carole (1987). "Preschoolers' Understanding of the Informational Function of Television Advertising”, Journal of Consumer Research, 14, 229-239.

Maxwell, Joseph A. (2nd ed.) (1996). Qualitative Research Design: An Interactive Approach. Sage Publications.

Morse, J.M., Barret, M., Mayan, M., Olson, K. \& Spiers, J. (2002). "Verification Strategies for Establishing Reliability and Validity in Qualitative Research", International Journal of Qualitative Methods, 1(2), 1-19.

Moschis, George P. \& Moore, Roy L. (1979), "Decision Making Among the Young: A Socialization Perspective", Journal of Consumer Research, 6, 101-112.

Moschis, George P. (1985). "The Role of Family Communication in Consumer Socialization of Children and Adolescents". Journal of Consumer Research, 11, 898913. 
Robertson, T.S. \& Rossiter, J.R. (1974). “Children and Commercial Persuasion: An Attribution Theory Analysis", Journal of Consumer Research, 1, 13-20.

Roedder, Deborah John \& Whitney, John C. (1986). "The Development of Consumer Knowledge in Children: A Cognitive approach", Journal of Consumer Research, 12, 406-417.

Roedder, Deborah L. (1981). “Age Differences in Children's Responses to Television Advertising: An Information Processing Approach”, Journal of Consumer Research, $8,144-153$.

Schiffman, Leon G. \& Kanuk, Leslie Lazar (8th ed.) (2004). Consumer Behavior. New Jersey: Prentice Hall.

Siedman, Irving (1998). Interviewing as Qualitative Research.

\section{APPENDIX}

The interview questions were as follows:

\section{For Children}

Ice breakers

- What is your name?

- Which class do you study in?

- How was your day today?

- What games did you play today?

\section{Research Related Questions}

\section{Supermarkets}

- Do you like going out with your parents?

- Where do they usually take you along? The supermarket?

- How often do you go with them?

- Do they ask you if you want to buy something once in the supermarket?

- How do you feel if they do ask you?

- How do you feel when they don't ask you if you want to buy something?

- How do you react to a product that you like?

- If your parents don't purchase that product for you, how do you feel?

- Do you understand your parents when they refuse a product purchase?

- Why do you think parents refuse?

- When you want to buy something, whom do you approach first- Father, Mother or Grandparent? Siblings? 


\section{Product Category}

Food items:

- What food items do you like that your parents don't let you have?

- Why don't they?

- Give an example of a recent episode.

- Why do you think you reacted that way? Why do you think your parents reacted that way?

- How aware are you about health concerns that your parents might have?

- Do you really enjoy the food you get at home?

- What would you do if you wanted to buy Chili Mili and you know that your mother will say no?

Toys:

- When are you taken to a toy store? Special occasions like birthdays?

- How often do you buy a toy?

- Is it a toy that you wanted for a long time?

- What do you do when you want an expensive item like a video game? Do you wait for a special occasions like birthday etc. or do you just ask for one?

- How do your parents react to your demand?

- How do you react to their reaction?

- Why do you think that at times they satisfy your demands yet at others they simply don't?

- Do your parents ask you to work towards a toy? Like chores around the house?

- Do your parents give you goals to win a toy from them? What are they?

Clothing and accessories:

- How much say do you have in the kind of clothing you buy?

- Are you fashion conscious?

Wrap Up

- Did you fast today?

- Would you like some candy?

- Did you enjoy yourself?

Thank you for your wonderful participation! You are a star!

\section{For Parents}

Ice Breaker

- How are you today? Thank you for giving us some time from your busy schedules.

Research Related Questions

- How often do you take your child out for shopping at the supermarket?

- How does your child react to an unfulfilled demand? 
- Does your child always ask you to buy him/her something every time you take them along?

- Do you ever ask your child if he wants something from the supermarket?

- Do you always prepare food/lunch that is preferred by your child?

- If you refuse to a child's particular demand, what are the reasons?

- Give an example of a recent episode.

- How do you handle a situation where your child really desires something and you think that he should not be given that product? Why?

Wrap Up

We thanked the parents for giving us their time. We explained to them the nature of our research and shared what their children told us so that they may know what their children thought about their role in purchase decisions.

\footnotetext{
" "Strategic management" is a term now in vogue. It describes the formulation and implementation of strategies that adapt a company to its changing environment. By "strategic management," we refer to the formulation of company missions, purposes, and objectives; the policies and programs to achieve them; and the methods needed to assure that they are implemented. In the past, strategic management meant essentially adapting to the economic and technical environments. Now it means adapting also to the sociopolitical environment. Indeed, sociopolitical environmental forces are as dominant influences on corporate strategy as traditional market forces.
}

The concept of strategic management does not imply that managements formulate strategies only in response to current events. Quite the contrary, it means that managers try to anticipate future environmental forces so that they can take proactive measures to deal with them."

Steiner and Steiner. Business, Government and Society, A Managerial Perspective, p. 15. 